This article was downloaded by: [B-on Consortium - 2007]

On: 26 April 2011

Access details: Access Details: [subscription number 919435511]

Publisher Routledge

Informa Ltd Registered in England and Wales Registered Number: 1072954 Registered office: Mortimer House, 3741 Mortimer Street, London W1T 3JH, UK

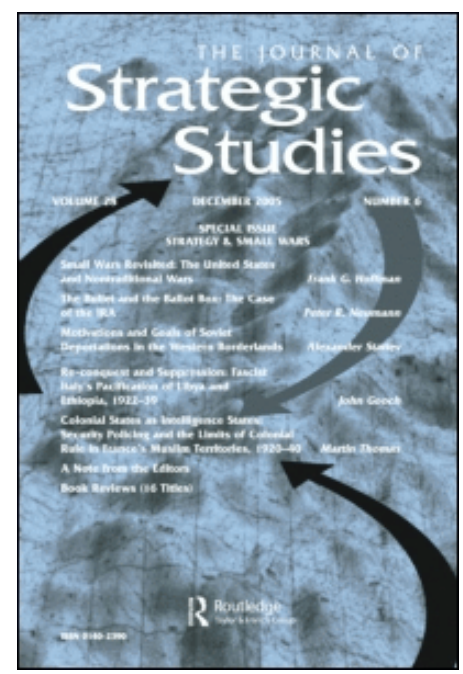

\title{
Journal of Strategic Studies
}

Publication details, including instructions for authors and subscription information:

http://www.informaworld.com/smpp/title content=t713636064

\section{The Myth of British Minimum Force in Counterinsurgency Campaigns} during Decolonisation (1945-1970)

Bruno C. Reis ${ }^{\text {ab }}$

${ }^{\text {a }}$ Post-Doctoral Researcher, Instituto de Ciências Sociais, Lisbon ${ }^{\mathrm{b}}$ Visiting Research Associate, Kings

College, London

Online publication date: 19 April 2011

To cite this Article Reis, Bruno C.(2011) 'The Myth of British Minimum Force in Counterinsurgency Campaigns during Decolonisation (1945-1970)', Journal of Strategic Studies, 34: 2, 245 - 279

To link to this Article: DOI: $10.1080 / 01402390.2011 .559028$

URL: http://dx.doi.org/10.1080/01402390.2011.559028

\section{PLEASE SCROLL DOWN FOR ARTICLE}

\footnotetext{
Full terms and conditions of use: http://www.informaworld.com/terms-and-conditions-of-access.pdf

This article may be used for research, teaching and private study purposes. Any substantial or systematic reproduction, re-distribution, re-selling, loan or sub-licensing, systematic supply or distribution in any form to anyone is expressly forbidden.

The publisher does not give any warranty express or implied or make any representation that the contents will be complete or accurate or up to date. The accuracy of any instructions, formulae and drug doses should be independently verified with primary sources. The publisher shall not be liable for any loss, actions, claims, proceedings, demand or costs or damages whatsoever or howsoever caused arising directly or indirectly in connection with or arising out of the use of this material.
} 


\title{
The Myth of British Minimum Force in Counterinsurgency Campaigns during Decolonisation (1945-1970)
}

\author{
BRUNO C. REIS \\ Post-Doctoral Researcher, Instituto de Ciências Sociais, Lisbon, and Visiting \\ Research Associate, Kings College, London
}

\begin{abstract}
This article argues that the dominant paradigm in studies of British small wars positing a central role of minimum force in doctrinal guidelines for counterinsurgency needs to be even more fundamentally revised than has been argued in recent debates. More specifically, it argues that minimum force is nowhere to be found in British doctrine during the small wars of decolonisation. The need for revision also applies to the way British counterinsurgency is usually sharply contrasted with French counterinsurgency. British doctrine during this period is better understood when placed in its proper historical context. This means comparing it with the other two most significant examples of doctrinal development for small wars of decolonisation - those of France and Portugal. This comparison shows that British counterinsurgency was not uniquely population-centric, and this characteristic cannot, therefore, be the reason for its arguably superior if far from infallible performance. Evidence for these arguments comes primarily from doctrinal sources developed specifically to deal with counterinsurgency, complemented with insights from key military thinkers and archival sources of relevance practices. Some wider implications of this analysis for the relationship between combat experience and doctrinal development as well as for counterinsurgency are identified.
\end{abstract}

KEY WorDS: Counterinsurgency, Colonial wars, Doctrine

\section{Challenging the Dominance of Minimum Force in Studies of British COIN}

Studies of British counterinsurgency have traditionally focused a great deal of attention on the small wars of decolonisation - particularly the success stories of Malaya (1948-60) and Kenya (1952-60) - positing a central role for minimum force in the doctrinal guidelines developed to 
deal victoriously with these insurgencies. The present article will argue that a central aspect of this traditional vision is fundamentally wrong: the alleged centrality of minimum force in British counterinsurgency during this period.

The core argument of this article is that alongside the failure to practise minimum force in the British small wars of decolonisation, a point that has attracted increasing attention in revisionist analysis, there is an amazingly unnoticed but, in fact, total absence of the principle of minimum force from official British military guidelines developed specifically for counterinsurgency overseas after 1945 and until as late as the early 1970s. Noting this absence is not necessarily a critique of British doctrine; it is, however, a major criticism of the way British counterinsurgency doctrine has so often been portrayed in existing studies, raising a number of important issues.

Yet, despite this doctrinal absence, can British counterinsurgency overseas during this period still be characterised as uniquely population-centric, and therefore fundamentally different from more coercive enemy-centric approaches to counterinsurgency? To answer this vital question, British counterinsurgency during decolonisation must be placed in its historical context. This will be done by examining it in comparison to the other two cases of similarly protracted decolonisation campaigns that led to significant doctrinal development for counterinsurgency: the often mentioned case of France, and the often neglected case of Portugal. A comparison between counterinsurgency as practised by Western colonial powers in a period of decolonisation seems to make more sense than to look at very different regimes such as Nazi Germany or the USSR, which were willing to resort to extreme force as a matter of course; or the American superpower in Vietnam, with its massive availability of firepower.

But our focus on the period of decolonisation has other reasons. After 1945, insurgents were often armed with modern weapons and nationalist slogans and benefited from cross-border sanctuaries, in contrast with the isolated, poorly armed, mostly tribal uprisings against colonialism that took place before the Second World War. These decades, therefore, saw the beginning of a trend of increasingly frequent and relevant intrastate wars. ${ }^{1}$ They also came to be seen as the classical era of counterinsurgency and rich in useful - particularly

\footnotetext{
${ }^{1}$ Michael Brown (ed.), Grave New World: Security Challenges in the Twenty-First Century (Washington DC: Georgetown UP 2003, 2-3, points out that only 18 per cent of conflicts between 1945 and 1995 have been conventional wars. For similar data for more recent years see SIPRI Yearbooks <www.sipri.org/contents/publications/ yearbooks.html >.
} 
British - lessons on how to win unconventional wars. ${ }^{2}$ Any significant revision of the dominant analysis of British counterinsurgency during this period therefore has important implications not only for the historical record regarding doctrine in specific decolonisation campaigns but also for our understanding of counterinsurgency. More specifically, this article should make us question whether present attempts to emulate past British successes in counterinsurgency have a solid historical basis.

A text of this length cannot be expected to offer exhaustive evidence of guidelines and practices in all British, French and Portuguese counterinsurgency campaigns. Still, a comparative analysis focused on supporting the claim that the existing literature on British counterinsurgency has tended to overemphasise its uniqueness in terms of minimum force is indispensable to support our core argument.

The key issues addressed in the main sections of this article are: What were the British doctrinal guidelines for fighting insurgencies and what role did minimum force play in them? Was British doctrine significantly different from French and Portuguese doctrine during their largely contemporary decolonisation campaigns? Before trying to offer answers to these questions, however, two subsections will provide a brief review of the relevant literature and definitions of key concepts.

\section{Studies of British Counterinsurgency and Minimum Force}

Where concise definitions of British counterinsurgency in existing studies are concerned, minimum force, or some close equivalent of it, is one of the most dominant labels, if not the most dominant label. A significant number of authors who have analysed British counterinsurgency refer to minimum force as a key doctrinal principle in the main British campaigns fought overseas after $1945 .^{3}$

Thomas Mockaitis, whose work has rightly been seen as a landmark in the study of British counterinsurgency, has been a particularly strong advocate of the centrality of minimum force in all major British

\footnotetext{
${ }^{2}$ For the salience of this era of classical COIN in today's strategic debates see, e.g., Frank Hoffman, 'Neo-Classical Counterinsurgency', Parameters 37/2 (2007), 71-87. ${ }^{3}$ E.g., and just to cite some of the most influential works that adhere to this notion: Colin McInnes, Hot War, Cold War: The British Army's Way in Warfare 1945-95 (London: Brassey's 1996) 116-17; David Charters, 'The British Adaptation to Low Intensity Operation from Palestine to Northern Ireland', in David Charters (ed.), Armies in Low-Intensity Conflict (London: Brassey's 1989), 228; Charles Townshend, Britain's Civil Wars: Counterinsurgency in the Twentieth Century (London: Faber and Faber 1986), 19; John Nagl, Counterinsurgency Lessons from Malaya and Vietnam: Learning to Eat Soup with a Knife (Westport: Praeger 2002), 205.
} 
campaigns after 1919, stating that: 'it would be difficult to exaggerate the importance of the principle of minimum force to British counterinsurgency'. ${ }^{4} \mathrm{He}$ also draws a sharp contrast between British and French counterinsurgency, with the Algerian campaign presented as a paradigmatic example of the 'bankruptcy of French methods' because of an unexplained propensity for brutal coercion and blind retaliation. ${ }^{5}$

In one of the few books conceived as a synthesis and guide to the literature on counterinsurgencies, Anthony Joes echoes this very strong trend in analyses of British counterinsurgency portraying it as using force 'to the minimum level possible' in its campaigns, and presenting British small wars of decolonisation as exemplary cases of success 'in contrast to the French tendency to resort to general punishment and intimidation'. ${ }^{6}$

It is true that there are increasing signs of a crisis in this minimum force paradigm, but so far it has resulted in partial and, in my view, insufficient revisions. A recent generic analysis of violence in the twentieth century, reflecting this significantly stated that while counterinsurgency had often been one of the reasons the century was so violent, yet the British 'defined a doctrine of "minimum force", although they did not always live up to it'.

Monographic studies have, indeed, documented in great detail, particularly in the case of Kenya, the extent to which British counterinsurgency could be very violent in practice. ${ }^{8}$ Articles published in a dossier on British counterinsurgency in Defense and Security Analysis were pertinently characterised as being part of an emerging trend towards a 'revision' of the prevailing vision of a 'softly, softly

\footnotetext{
${ }^{4}$ Thomas Mockaitis, 'The Origins of British Counter-Insurgency', Small Wars and Insurgencies, 1/3 (1990), 213.

${ }^{5}$ Thomas Mockaitis, British Counterinsurgency 1919-1960 (London: Macmillan 1990), 56 passim; Thomas Mockaitis, 'A New Era of COIN', RUSI Journal, 136/1 (1991), 75.

${ }^{6}$ Anthony Joes, Resisting Rebellion: The History and Politics of Counterinsurgency (Lexington: U of Kentucky P 2006), 221-2. Pointedly, the author exempts the mature stage of the Algerian campaign from this failure.

${ }^{7}$ Mark Mazower, 'Violence and the State in the Twentieth Century', The American Historical Review, 107/4 (2002), 1175.

${ }^{8}$ On Kenya see David Anderson, Histories of the Hanged: Britain's Dirty War in Kenya and the End of Empire (London: Weidenfeld and Nicolson 2005); Caroline Elkins, Imperial Reckoning: The Untold Story of Britain's Gulag in Kenya (New York: Henry Holt 2005). As example of the debate these books generated see Neal Ascherson, 'The Breaking of the Mau Mau', New York Review of Books, 52/6 (2005), <www.nybooks.com/articles/17896 > ; David Elstein, 'The End of The Mau Mau', New York Review of Books, 52/11 (2005), <www.nybooks.com/articles/18096>.
} 
approach' in British counterinsurgency ${ }^{9}$ and the same could be said of another even more recent dossier on the subject in the Journal of Strategic Studies. ${ }^{10}$

But the break with a paradigm of British counterinsurgency triumphant after 1945 because of minimum force is still far from prevalent or clear enough. Rod Thornton, in particular, has given the paradigm of minimum force renewed force by defending not only the importance of it in British counterinsurgency but also that it has deeper historical roots than even Mockaitis and others had argued, being important in counterinsurgency campaigns earlier than 1919, therefore making the principle of minimum force in British counterinsurgency even older, more specific and more salient. ${ }^{11}$ In a recent debate he reiterated this point of view in response to criticism of the minimum force paradigm. ${ }^{12}$

While there are some texts that point to some problems with the dominant view of British counterinsurgency; their focus, however, is on specific campaigns and on the differences between doctrinal principles and coercive practices. A good example of this is Huw Bennett's debate with Rod Thornton regarding the lightness of the empirical evidence of the practice of minimum force as opposed to strong evidence of retaliatory practices. ${ }^{13}$ But in the end Bennett focused too much on the differences between doctrinal principles and coercive practices and goes too far - for reasons presented in the next subsection - in generically questioning the significance of doctrine in counterinsurgency or even in military campaigns in general but not far enough in not fundamentally questioning the traditional assumption of the existence of a generic British doctrinal principle of minimum force for counterinsurgency throughout the entire period of the decolonisation campaigns.

This norm-versus-practice approach to the problem of minimum force is, in fact, not entirely new. Examples of it can be found even in the work of authors who use it to continue to advocate the importance of minimum force. For instance, the British campaign in Kenya (1952-

\footnotetext{
${ }^{9}$ Thomas G. Mahnken, 'The British Approach to Counter-Insurgency: An American View', Defense and Security Analysis, 23/2 (2007), 230-31. This introduction syntheses this thematic issue of the journal.

${ }^{10}$ Paul Dixon, "'Hearts and Minds?" British Counter-Insurgency from Malaya to Iraq', Journal of Strategic Studies, 32/3 (2009), 353-81.

${ }^{11}$ Rod Thornton, 'The British Army and the Origins of its Minimum Force Philosophy', Small Wars and Insurgencies, 15/1 (2004), 83-106.

${ }^{12}$ Rod Thornton, “"Minimum Force”: A Reply to Huw Bennett', Small Wars and Insurgencies, 20/1 (2009), 215-26.

${ }^{13}$ Huw Bennett, 'British Minimum Force', Small Wars and Insurgencies, 21/3 (2010), 459-75.
} 
60) resulted in a debate between Newsinger and Mockaitis, with the latter accepting that Kenya was an example of abuses, but insisting they were atypical practices committed mostly by local militias and that there was therefore no need for a fundamental revision of the centrality of minimum force as a norm in British army counterinsurgency doctrine. ${ }^{14}$ Newsinger insisted that Kenya was an 'important exception' to the norm in practice, but still accepted that as a rule there was a 'relative restraint of British counterinsurgency' when compared with its French, Dutch or Portuguese counterparts. ${ }^{15}$

These limited revisions are insufficient. What is required is a clear recognition of the absence of minimum force as a rule and in principlei.e., in official doctrine - as well as in practice, in British counterinsurgency during the entire period of the small wars of decolonisation. In fact, as this article will show, theatre-specific doctrine especially developed for ongoing campaigns provides important evidence, ignored in debates so far, of the absence of a minimum force guideline for counterinsurgency during Britain's decolonisation campaigns.

\section{Defining Counterinsurgency Doctrine and Minimum Force}

Counterinsurgency is understood here to be a form of asymmetrical armed conflict where one side, the insurgents or guerrillas, is fundamentally weaker than the counterinsurgents or conventional armed forces and therefore has to organise differently both for the purposes of combat and to violently challenge the political status quo. If insurgency is 'the armed expression' of 'internal political disaffiliation'; counterinsurgency, to achieve even minimal success, must be a form of armed state (re)building. ${ }^{16}$

Military doctrine is defined in this article as officially sanctioned guidelines, since authoritative norms are consensually seen as doctrine, whether or not other elements are then added to this core. References to semiformal or informal doctrine seem potentially

\footnotetext{
${ }^{14}$ John Newsinger, 'Minimum Force, British Counter-Insurgency and the Mau Mau Rebellion', Small Wars and Insurgencies, 3/1 (1992), 47-57; Thomas Mockaitis, 'Minimum Force, British Counter-Insurgency and the Mau Mau Rebellion: A Reply', Small Wars and Insurgencies, 3/2 (1992), 87-9.

${ }^{15}$ John Newsinger, British Counter-Insurgency from Palestine to Northern Ireland (Basingstoke: Palgrave 2002), 1-2.

${ }^{16}$ Larry Cable, 'Reinventing the Round-Wheel: Insurgency, Counterinsurgency, and Peacekeeping Post Cold War', Small Wars and Insurgencies, 4/2 (1993), 229. For a recent discussion with ample references see David Betz, 'Insurgency and Counterinsurgency', in Robert Denemark et al. (eds.), The International Studies Encyclopedia, Blackwell Reference Online, <http://www.isacompendium.com/subscriber/tocnode? $\mathrm{id}=$ g9781444336597_chunk_g978144433659711_ss1-10 > .
} 
confusing. ${ }^{17}$ However, this is not the same as arguing that military thinking or more informal aspects of military culture are unimportant; rather, it is an argument for definitional clarity.

Traditionally, studies of military doctrine have concentrated on nuclear or conventional warfare thus following a wider pattern in strategic studies. For a long time, small colonial wars were apparently considered to be too small and too peripheral to deserve much notice in security studies. ${ }^{18}$ This article hopes to help redress that imbalance. ${ }^{19}$

Why is doctrine relevant? In debating the centrality of minimum force in British counterinsurgency it is crucial to establish whether or not this principle was present in the main official guidelines issued specifically to deal with guerrilla warfare in such paradigmatic campaigns as Malaya and Kenya. It seems highly unlikely that a disciplined organisation like the Armed Forces, which requires intensive training and a hierarchical chain of command, would issue new counterinsurgency guidelines in the middle of ongoing campaigns yet somehow failed to include the allegedly central principle of minimum force. It is also hardly credible to claim that these new manuals, developed to deal specifically with ongoing counterinsurgencies, had no significant connection with lessons learned or existing practices.

Given the specific aim of our analysis, this article will primarily focus on the first of these two elements, i.e., on establishing the nonexistence of a principle of minimum force in British doctrine for counterinsurgency between 1945 and 1970 because this wrong starting point, is seemingly accepted by even those critical of the minimum force paradigm. Consequently, the crucial evidence required to make our case will come from manuals. But some attention will be given to other evidence of practices from other relevant sources: books of military thinkers, memoirs and archival documents.

To evaluate the impact of minimum force, we must first understand what the concept means. This doctrinal principle emerged in Britain in the early nineteenth century as part of a process of political liberalisation

\footnotetext{
${ }^{17}$ See, e.g., Keith Bickel, Mars Learning: The Marine Corps Development of Small Wars Doctrine, 1915-1940 (Boulder: Westview 2001), 4-7; Paul Dixon, "'Hearts and Minds?” British Counter-Insurgency from Malaya to Iraq', Journal of Strategic Studies, 32/3 (2009), 357.

${ }^{18}$ Michael Howard, 'The Military Factor in European Expansion', in H. Bull (ed.), The Expansion of European Society (Oxford: Clarendon P 1984), 34-35.

${ }^{19}$ For data on this imbalance, see Ian Beckett, 'Low-Intensity Conflict: Its Place in the Study of War', in D.A. Charters et al. (eds), Military History and the Military Profession (Westport: Praeger 1992), 121-9; for plausible explanations of this fact, see John Shy and Thomas Collier, 'Revolutionary War', in P. Paret (ed.), Makers of Modern Strategy: From Machiavelli to the Nuclear Age (Oxford: Clarendon P 1986), 815-62.
} 


\section{Bruno C. Reis}

and, consequently, of softening of political repression. It required British officers to deal with internal unrest with the minimum force necessary in a given context, and it necessarily begs the questions: minimum in relation to what maximum, and necessary under what circumstances? As General Napier put it in 1837, using minimum force to deal with unrest in Britain placed him in a predicament: 'Should I be shot for my forbearance by a court martial, or hanged for over zeal by a jury? ${ }^{20}$ The intrinsically flexible and contextual nature of the concept of minimum force is especially relevant in a colonial context. Even in peacetime, British colonies were not models of democratic governance; therefore minimum force, particularly overseas, could 'stray perilously close to merely rewriting the laws to cover any required actions'. ${ }^{21}$ Minimum necessary force could, even in principle, mean using quite a lot of force legally. But the problem with minimum force in British counterinsurgency overseas after 1945 was more fundamental than this.

\section{Minimum Force Missing from British Counterinsurgency Doctrine}

This section looks at the basic British guidelines for counterinsurgency after 1945 and examines why they do not fit the traditional paradigm, which gives a central role to minimum force. This analysis will focus on the most doctrinally relevant British campaigns - Malaya (1948-60) and Kenya (1952-60) - both of which resulted in important counterinsurgency manuals. Another crucial source will be the first generic British manual specifically devoted to counterinsurgency. Issued in 1970 , i.e., at the very end of the period of decolonisation, it provides an official summary of doctrinal developments during this period.

\section{The Absence of Minimum Force from Counterinsurgency Manuals}

Manuals dealing with counterinsurgency between 1945 and 1970 should be the starting point for any analysis of the role of minimum force in the British small wars of decolonisation. They contain the doctrinal guidelines developed to deal authoritatively and specifically with counterinsurgency during this period. However, when we focus on these principles minimum force is nowhere to be seen: it is absent from the Malaya and Kenya campaign manuals, as well as from the first generic manual on counterinsurgency.

But if minimum force is so completely absent from official guidelines, where does the reference to its centrality come from? It comes from

\footnotetext{
${ }^{20}$ Townshend, Britain's Civil Wars, 20.

${ }^{21}$ Ibid., 23.
} 
doctrinal guidelines on the use of military force in aid to the civil power in response to lesser internal security challenges. This confusion probably arises for two main reasons: first, the absence of a generic doctrine dealing specifically with counterinsurgency before 1970; second, the fact that insurgencies tended to be downplayed in official discourse for political reasons as mere internal security problems, even if the military did not treat them as such for long.

The nature of the connection of this body of doctrine on aid to the civil power with counterinsurgency specifically is therefore essential in establishing the role of minimum force in late colonial British small wars. Mockaitis, a key advocate of the minimalist view of British counterinsurgency in the period of interest to us, argues that 'the principle of minimum force was broadened further in 1949' with a new manual on Imperial Policing and Duties in Aid of the Civil Power resulting in a very significant 'combination in one manual of what had previously been handled in two'. ${ }^{22}$ This is wrong, not only because this combination was more a matter of addition than of effective fusion more than half of the pages of the 1949 manual were specifically focused on deployments within the United Kingdom only; ${ }^{23}$ but also because the allegedly straightforward connection between internal security doctrine and counterinsurgency during the small wars of decolonisation is extremely problematic, to say the least. As was bluntly noted by a keen observer of military doctrine at the time of these campaigns - an author therefore free from any present-day analytical bias on this matter - counterinsurgency after 1945 was 'a very different problem from the gesticulating, half-comic figures of the traditional mob familiar from generations of Staff College "playlets" on "duties in aid of the civil power". Buglers and banners inscribed "Disperse or I fire" ... were of marginal use in these vicious little wars. ${ }^{24}$ But what were then the doctrinal principles developed to deal specifically with small wars after 1945?

\section{British Counterinsurgency Manuals and the Use of Force}

Before 1970 only campaign manuals for Malaya and Kenya dealt specifically with counterinsurgency. These doctrinal rules of engagement in the case of Malaya and Kenya actually gave a great deal of

\footnotetext{
${ }^{22}$ Thomas Mockaitis, British Counterinsurgency 1919-1960 (London: Macmillan 1990), 134.

${ }^{23}$ War Office, Imperial Policing and Duties in Aid of the Civil Power (London: HMSO 1949), ch. III.

${ }^{24}$ Alun Jones, 'Training and Doctrine in the British Army since 1945', in M. Howard (ed.), The Theory and Practice of War (Bloomington: Indiana UP 1965), 318.
} 


\section{Bruno C. Reis}

leeway to British troops. This is also the case in other less well-known and less successful - significantly both in terms of doctrinal development and practice - British campaigns of decolonisation, such as those that took place in Palestine or Cyprus. ${ }^{25}$

The manuals developed specifically for counterinsurgency did reflect the legal concerns of British military culture, but not in a way that can be equated with minimum force. In the Malayan campaign manual there was a detailed section devoted to Emergency Regulations. However, the dominant tone was enabling not restrictive: it was oriented towards showing how this special legislation could be put to the best possible operational use. ${ }^{26}$ These regulations included: the right to shoot without warning in war areas; or in all areas after due warning; or in order to prevent captured insurgents from escaping, which amounted to a potential blank cheque for summary executions; as well as virtually unlimited powers of detention, deportation, resettlement and collective punishment. The Malayan campaign manual was restrictive mainly with regard to respect for local customs, e.g., in dealings with halal food or local women. It is true that in its second edition the manual explicitly warned against confessions obtained by resorting to any 'inducement, threat or promise' and insisted that after an area had been cleared for military operations it should not be regarded as a free shooting zone. ${ }^{27}$ This is significant not only because it shows that these problems were sufficiently common to deserve explicit reference in an attempt to impose greater restraint but also because it did not make any reference to a principle of minimum force in order to justify or clarify this doctrinal revision.

Kenya provides especially relevant evidence of the far-fromstraightforward nature of the relationship between doctrinal principles for counterinsurgency and those of minimum force in doctrine concerning aid to the civil power. When the insurgency started, in 1952, a revised version of the 1945 edition of the local manual with

\footnotetext{
${ }^{25}$ A point made by some historians of the British Empire, e.g., Ronald Hyam, Britain's Declining Empire: The Road to Decolonization (Cambridge: Cambridge UP 2006), 36, 57, 264 passim; on brutal repression and official counterterror in Palestine see, e.g., Jacob Norris, 'Repression and Rebellion: Britain's Response to the Arab Revolt in Palestine of 1936-39', Journal of Commonwealth Imperial History, 36/1 (2008), 26; Tom Segev, One Palestine, Complete (New York: Owl Books 2001), 415-35; Charles Townshend, 'In Aid of the Civil Power: Britain, Ireland, and Palestine 1948', in D. Marston et al. (eds), Counterinsurgency in UK-Modern Warfare (Wellingborough: Osprey 2008), 31-32; for Cyprus see Robert Holland, Britain and the Revolt in Cyprus 1954-1959 (Oxford: Clarendon P 1998).

${ }^{26} \mathrm{UK}$ - HQ-Malaya Command, The Conduct of Anti-Terrorist Operations in Malaya (ATOM), 2nd Rev. Ed. (Kuala-Lumpur: HQ-MC 1954), ch. IV.

${ }^{27}$ Ibid., ch. IV/1.
} 
Instruction on the Use of Armed Force in Civil Disturbances was ready to be issued. However, the military authorities objected to its publication at a time of full-blown insurgency. Why? Because it would create doctrinal confusion. Clearly, there was no straight path, quite the opposite, between the doctrinal principles of minimum force regarding internal security and counterinsurgency proper. ${ }^{28}$

The campaign report of the top British commander in Kenya, General Erskine, who is usually credited with winning the campaign against the Mau Mau, helps us to go deeper into the problematic nature of the traditional paradigm of minimum force as central in British counterinsurgency. He states that only in so-called 'special Areas', marginal to the core areas of counterinsurgency proper, did security forces have to act 'selectively' and 'use the minimum force as judged by the Officer in Command'. And even in these areas 'anybody could be called on to halt for purpose of examination and if the person did not halt after challenged, fire could be opened'. But more importantly for the argument of this article, General Erskine also states that 'the most important of these [Emergency] Regulations provided for Prohibited Areas' where 'troops were able to operate on a straightforward war basis'. These words show a revealing bias towards using force as unconstrained as possible in counterinsurgency proper. ${ }^{29}$

Erskine's testimony shows that while minimum force may sometimes have been marginally present in late colonial British counterinsurgency campaigns its importance has been widely exaggerated. For instance, in the case of Kenya, it is clear that Erskine was determined to change his troops' modus operandi in order to make them more effective counterinsurgents, commissioning a Handbook of new doctrinal guidelines specifically for that purpose. But Erskine was unwilling to adopt minimum force as the central doctrinal principle of his counterinsurgency campaign, hence its total absence from that Handbook.

The evidence from the British campaign in Kenya leads us to concur with the analysis that 'the oft-assumed national inhibitor, the principle of "minimum force", was actually' in this case, but also in other British small wars of decolonisation 'widely permissive'; and that 'harsh measures were seen as necessary and effective' and resulted from a strategic option not 'a disciplinary breakdown'. Therefore it seems reasonable to conclude that indeed 'it is time for a re-evaluation of the significance of minimum force in British counterinsurgency, as

\footnotetext{
${ }^{28}$ TNA, WO 276/138, Internal Security Publications, e.g., Letter from E.W. Magor UKMoD Kenya to Mj. Gen. Heyman GHQ EAfrica (27 Aug. 1954).

${ }^{29}$ TNA, WO 236/18 Report on the Kenya Emergency Gen. Sir G. Erskine 7 May 195325 May 1955. UK-East Africa-GHQ, A Handbook of Anti-Mau Mau Operations (Nairobi: EA-GHQ 1954).
} 
illustrated by the Kenya Emergency case' in others cases. ${ }^{30}$ But this article goes further than this by showing that this paradigm of the centrality of minimum force was largely a myth, not only because of its flexibility in practice, as Bennett claims, but also because of its absence in late colonial doctrinal principles themselves.

The British manual on counterrevolutionary warfare which came out in 1970 was the first to deal specifically and exclusively with counterinsurgency outside of the context of a particular campaign, therefore providing crucial evidence on the role of minimum force in the canon of British counterinsurgency doctrine that emerged during this period of decolonisation. If minimum force was in fact such a central doctrinal principle, why is it not present where one would expect to find it: in the list of four 'Ingredients of Success for Counterinsurgency'? ${ }^{31}$ Minimum force did not qualify for that distinction or, in fact, for any mention. Furthermore, the section of the 1970 manual that deals with 'counter-ambush measures' - a central task in counterinsurgency - states that it 'must be made clear to the insurgents that any road ambushes will result in swift, devastating retaliation from the security forces.' This is in obvious contradiction with the way that minimum force in British counterinsurgency has traditionally been portrayed in stark contrast with French counterinsurgency's emphasis on retaliation. ${ }^{32}$

\section{Minimum Force: Doctrine versus Practice?}

This subsection seeks to counter an important counterargument against the main claim of this article by those like Bennett who argue that there was a very significant difference between doctrine and practice in British counterinsurgency during decolonisation. To address this point is even more important given the often mentioned pragmatism, flexibility and anti-intellectualism of British officers. ${ }^{33}$

\footnotetext{
${ }^{30}$ Huw Bennett, 'The Other Side of COIN: Minimum and Exemplary Force in British Army Counterinsurgency in Kenya', Small Wars and Insurgencies, 18/4 (2007), 638, 657.

${ }^{31}$ UK - Ministry of Defence, Land Operations: Vol. III: Counter-Revolutionary Operations: Part 3. Counter Insurgency, Army Code 70516 (Part 3) (London: HMSO Jan. 1970), 4-5.

${ }^{32}$ UK - Ministry of Defence, Land Operations: Vol. III: Counter-Revolutionary Operations: Part 3. Counter Insurgency, Army Code 70516 (Part 3) (London: HMSO Jan. 1970), 57.

${ }^{33}$ See, e.g., John Nagl, Counterinsurgency Lessons from Malaya and Vietnam: Learning to Eat Soup with a Knife (Westport: Praeger 2002), 36-7 passim.
} 
Two lectures on counterinsurgency given by General Stockwell in a relatively short period of time offer a rare glimpse into the difficult issue of the relationship between principles and practices during the period when the earliest efforts were being made to develop a new doctrine to deal specifically with counterinsurgency. In 1950 and again in 1953, he was invited to deliver lectures at the Staff College on counterinsurgency in Palestine and Malaya. The approach he took on the two occasions varied significantly. In 1950, Stockwell felt obliged to warn that he was merely offering 'a colour picture as a background to your study of Internal Security duties'; i.e., 'particular examples' from Palestine should not distract officers from the 'study of the pamphlet - Imperial Policing' as the only authorised source of 'general principles'. ${ }^{34}$ This might be read as an unequivocal endorsement of official doctrine on aid to civil power. But the terms in which it was made, and especially a second lecture on the same subject only a few years later, point to a growing tension between the need for new specific guidelines based on practical lessons learned from fighting insurgencies on the ground, and the old official guidelines developed not for counterinsurgency proper but for lighter internal security duties.

Indeed, in Stockwell's next lecture on the same subject, in 1953, he used the new formal doctrine developed to deal specifically with counterinsurgency, even if, stricto sensu, the authority of these new guidelines was limited to Malaya. Yet Stockwell's notes show that in presenting the lessons learned in the case of counterinsurgency in Malaya he chose not only to follow closely the manual developed for that campaign, but also not to make any reference to other sources of doctrine. ${ }^{35}$ This provides early evidence of the impact of ATOM (with its absence of minimum force) at the heart of the British Army establishment, even if 'not until 1961 was the Malayan manual put on the syllabus at Camberley'. ${ }^{36}$

Stockwell's lectures also show the limits of the often mentioned pragmatism, informality, and flexibility of British officers. In this case, even a very senior officer clearly subordinated his experience to formal guidelines. These lectures also help to document the importance of the development of specific guidelines for counterinsurgency based on ongoing campaigns in the 1950s. After all, why would new manuals be

\footnotetext{
${ }^{34}$ NAM, Templer Papers 7410-29-1-10, LHCMA-KCL LH 1/682 Letter Templer to Liddell Hart LHCMA - KCL, Stockwell Papers 7/4 LHCMA-KCL, Stockwell Papers, 6/29/2, I.S. Lecture Staff College [Mar. 1950].

${ }^{35}$ LHCMA-KCL, Stockwell Papers, 6/3, Training for Anti-Guerrilla Warfare (s.d.), IDEM, Stockwell Papers, 6/7, Vade-Mecum: The Army in the Cold War Operations (Malaya).

${ }^{36}$ Mockaitis, British Counterinsurgency, 134.
} 
developed specifically for counterinsurgency in Malaya and Kenya if preexisting doctrine on internal security had been adequate? The same logic would force us to recognise the very real significance of the fact that minimum force played no part in manuals on counterinsurgency proper during the most successful British campaigns in Malaya and Kenya.

Moreover, minimum force is also significantly absent from the books published by the major British military thinkers on counterinsurgency during this period. This is especially significant for two reasons. First, because these authors - Kitson, Paget and Thompson being probably the most well-known - were deeply involved in developing and applying as well as publicly promoting the British approach to counterinsurgency. Any alleged informal or semiformal doctrine of minimum force should therefore logically find some expression in their work. If it is neither there nor in official guidelines, then where is minimum force in counterinsurgency during this period between 1945 and 1970? Second, because, in publishing books accessible to the general public, these authors would have a strong incentive to underline any softer, more acceptable side of British counterinsurgency. Yet minimum force is nowhere to be found.

General Kitson, when asked by the Ministry of Defence in the early 1970 s to devote one year to the writing of a book summarising his vast experience of counterinsurgency going back to Kenya in the early 1950s, did not make a single reference to minimum force. He did believe that 'politicians' would seek to 'avoid the use of force' in dealing with internal disturbances, but he also made clear that 'there are military difficulties in using too little force and about delaying its application for too long'. Moreover, Kitson insisted that 'however great the restrictions imposed on the use of force' still 'every effort' should be made by the military 'to build an impression of strength'. ${ }^{37}$

On the basis of his Malayan experience, Sir Robert Thompson did insist that the temptation to simply ignore the law was a serious strategic mistake in counterinsurgency. But not only was the principle of minimum force absent from Thompson's texts, namely from his influential list of five key ingredients for victory in counterinsurgency, he also made clear that his concern was motivated by the need to fight an insurgency by building a stronger state, which should be done by toughening the law according to strategic necessity, not by acting in a blindly violent way. ${ }^{38}$ Even in a later work, aimed at convincing

\footnotetext{
${ }^{37}$ Frank Kitson, Low Intensity Operations: Subversion, Insurgency, Peacekeeping (London: Faber and Faber 1971), 3, 69-70, 90.

${ }^{38}$ Robert Thompson, Defeating Communist Insurgency: Experiences from Malaya and Vietnam (London: Chatto and Windus 1966), 50-5.
} 
Western audiences of the need to stay in Vietnam, Thompson did not insert any reference to the ability to win a counterinsurgency using minimum force, which, given the apologetic purpose of the book would be very convenient. ${ }^{39}$

Despite all this, if British troops had no authoritative doctrine specifically for counterinsurgency - which with the exception of Malaya and Kenya was the case until the generic manual of 1970 was issued - one could still ask whether minimum force might have been employed by default.

A recent documentary series on the British wars of decolonisation offers significant evidence that this was not the case, with important testimonies from all the major campaigns about deadly special operations and other examples of major use of force; no less revealing are some refusals to talk about more controversial issues justified by the need to leave certain things unsaid. ${ }^{40}$ In answering this question the failed British counterinsurgency campaign in Aden and South Arabia (1963-67) is especially important, because it took place after the successful counterinsurgencies in Malaya and Kenya, in which theatrespecific doctrine had been developed, but before an Army-wide doctrine on counterinsurgency was issued in 1970. A new study of the military campaign in South Arabia 'depressingly' but significantly concluded that there was a lack of any visible significant learning by the British army either from experience or from other previous counterinsurgency campaigns. ${ }^{41}$ This should make us question the extent to which 'imperial networking provided a kind of doctrinal continuity' of British counterinsurgency principles, regardless of whether or not it included minimum force. ${ }^{42}$ More importantly for the central argument of this article, the campaign in South Arabia provides strong evidence that it is wrong to claim that in the absence of specific counterinsurgency guidelines minimum force would prevail by default. Colonel Julian Paget, who played a central role in that campaign, leaves no room for doubt:

Internal Security operations, otherwise known as duties in aid of the Civil Power, are not to be confused with counterinsurgency; they are aimed at controlling civil disturbances and are based on

\footnotetext{
${ }^{39}$ Robert Thompson, No Exit from Vietnam (New York: David MacKay 1969), 163. ${ }^{40}$ Jenny Ash, Empire Warriors (London: BBC 2004) [2 DVDs - 2006], the four episodes are on Palestine, Malaya, Kenya, Aden and South Arabia.

${ }^{41}$ Jonathan Walker, Aden Insurgency: The Savage War in South Arabia 1962-1967 (Staplehurst: Spellmount 2005), 288.

${ }^{42}$ Townshend, 'In Aid of the Civil Power', 36.
} 
principles of the use of minimum force, which does not apply in actions against insurgents. ${ }^{43}$

There is no indication that he regarded this matter-of-fact statement as in any way controversial, much less contrary to a British Army norm. Therefore, in Aden, the last major British small war of decolonisation, minimum force is for the most part invisible, in principle as well as in practice, despite the fact that this was already a highly mediatised campaign taking place as late as the late 1960s. And yet the persistent nature of the minimum force paradigm, even among authors who are more critical of an increasingly incredible softly, softly portrayal of British counterinsurgency doctrine, is demonstrated by the fact that a recent article, which adopts a moderately revisionist point of view, somehow still cites Paget as evidence of the principle of minimum force in British counterinsurgency. ${ }^{44}$

An important point on the question of the relationship between doctrine and practice in these counterinsurgency campaigns is the fact that small wars, as General Erskine's Foreword to the Kenyan campaign Handbook states, place 'much responsibility on junior leaders and even individual soldiers'. ${ }^{45}$ But this does not necessarily contradict the need for formal doctrine. As Thompson highlighted, this was a 'junior commander's war' but 'no junior commanders would dare to take action without superior orders'. ${ }^{46}$ It was precisely for this reason that counterinsurgency manuals were so important. They helped to make clear that lower and middle-ranking officers were expected to play an active role in counterinsurgency, while offering them some generic guidelines on how best to proceed in this very unconventional type of conflict.

Another crucial point regarding the relationship between combat experience and doctrine is made by the most emblematic figure of British counterinsurgency, General Templer, who states in the opening lines of the famous manual he sponsored:

I have been impressed by the wealth of jungle fighting experience available on different levels in Malaya ... I have been disturbed by the fact that this ... has not been properly collated or presented to those whose knowledge and experience is not so great.... Hence this book. ${ }^{47}$

\footnotetext{
${ }^{43}$ Julian Paget, Counterinsurgency Campaigning (London: Faber and Faber 1967), 15.

${ }^{44}$ Dixon, "'Hearts and Minds?",, 359.

${ }^{45}$ George Erskine, 'Foreword', in A Handbook of Anti-Mau Mau Operations (Nairobi: EA-GHQ 1954).

${ }^{46}$ Thompson, Defeating Communist Insurgency, 61.

${ }^{47}$ Sir Gerald Templer, 'Foreword', in The Conduct of Anti-Terrorist Operations in Malaya [ATOM] (Kuala-Lumpur: HQ-MC 1954), xi.
} 
This quintessential example of British counterinsurgency doctrine explicitly pooled, reflected upon and distributed lessons gained from combat experience. In other words, doctrine does not emerge out of nowhere. The best way to account for the absence of minimum force from British doctrinal principles and military thinking on counterinsurgency during these crucial years of its development is therefore simply to conclude that this reflected and reinforced the fact that minimum force was not present, in so far as we can document it, in most of British practice in the small wars of decolonisation. Or as an internal British Army document put it as late as 1972, counterinsurgency was defined as 'military activities involving the restoration of law and order which are NOT conducted in accordance with the principle of minimum force'. ${ }^{48}$

\section{Comparing British with French and Portuguese Counterinsurgency Doctrines}

Is British population-centric doctrine, however, still fundamentally different from other examples of counterinsurgency? This section will provide evidence for a negative answer to that question regarding doctrinal developments in nearly contemporary small wars of decolonisation. The focus will be on the French case - so often cited, and so often quickly dismissed - but some references will also be made, when pertinent, to the Portuguese case.

\section{Winning Local Hearts and Minds is Not a British Specificity}

A notion closely linked with British counterinsurgency and minimum force is a slogan popularised by General Templer during the Malayan campaign: 'the answer to our present problems and frustrations ... lies in the hearts and minds of the men, women and children of this country'. ${ }^{49}$ But how specifically British is this population-centric concern with winning over local civilians as vital to victory in counterinsurgency?

A very similar concern with gaining the support of the local population, and not merely killing insurgents or brutally coercing civilians was also an essential part of both the French and Portuguese counterinsurgency guidelines issued in the 1950s and 1960s. It is even

\footnotetext{
${ }^{48}$ TNA, WO 32/21748 Counter Revolutionary Operations Study, Directorate of Army Training, Note on Terminology (13 Oct. 1972, emphasis in original).

${ }^{49}$ NAM, Templer Papers 7410-29-1-10, Gerald Templer - Address to the [Malayan] Chamber of Commerce (25 Apr. 1952). The audience of businessmen is also significant: they could help him in this regard, by improving the lot of the common people.
} 


\section{Bruno C. Reis}

possible to argue that in both the French and Portuguese cases, this concern with winning over locals played a more central role than it did in the British case, or at least led to a greater transformation of the military.

Entirely new (fifth) sections in charge of civilian affairs and psychological warfare were created in military HQs in both the French and Portuguese armies. These tasks were seen as so vital for success that French and Portuguese military leaders felt that they had to control them and take them into consideration when planning and executing all counterinsurgency operations. More importantly for the key concern of this article, specific Portuguese and French military doctrine on psychological warfare was developed to provide guidance to officers dealing with civilian affairs and propaganda. ${ }^{50}$

The official lessons of the French campaign in Indochina had concluded that the failure there had largely been due to the absence of this population-centric dimension, despite some belated steps to develop it, 'hampered by lack of adequate personnel'. ${ }^{51}$ As a consequence, a new body of French civilian affairs officers was created in Algeria building upon an older tradition of colonial pacification but employing a new manual written specifically to make sure that they would be doctrinally equipped to fight a revolutionary war for the hearts and minds of Algerians. ${ }^{52}$ French doctrine on psychological warfare then had an important influence in the development of Portuguese doctrine. ${ }^{53}$

\section{Total War as the French Comprehensive Approach to Counterinsurgency}

Can a population-centric understanding of counterinsurgency be reconciled with the French notion of counterinsurgency as total war? This article will argue that, in fact, it was an indispensable part of it.

\footnotetext{
${ }^{50}$ SHD 1 H 2403 Commander-in-Chief X RM-EM, Directive pour l'Action Psychologique ... (2 July 1955); SHD 1H 2408, EMGFA-BP, Directive sur la Guerre Psychologique (4 Oct. 1955). Two important works of reference are: Pierre Pahlavi, La guerre révolutionnaire de l'armée française en Algérie (1954-1961): Entre esprit de conquête et conquête des esprits (Paris: L'Harmattan 2002); and Paul and Marie Villatoux, La Republique et son armée face au peril subversif: guerre et action psychologiques en France, 1945-1960 (Paris: Les Indes Savantes 2005).

${ }^{51} 10 \mathrm{H} 346$ EMIFT, Note de service 800 (4 Apr. 1953); see also SHD 10H 983 EMAT, Enseignements de la Guerre d'Indochine, Vol. 2: 11-29, 68. Raoul Salan, Mémoires: Fin d'un Empire, (Paris: Presses de la Cité 1970), Vol. 2, 306-9.

${ }^{52}$ France-Ministère de l'Algérie-Service Affaires Algériennes, Guide de l'officier des affaires algériennes (Paris: SAA 1959).

${ }^{53}$ Portugal-EME, O Exército na Guerra Subversiva [The Army in Subversive Warfare] (EGS), 5 vols. (Lisboa: EME-IAEM 1963), Vol. 3, chs. III to VI.
} 
Formal French counterinsurgency training guidelines, under the title 'Permanent Factors of Success', stated unequivocally that: 'this war is total. It must include all fronts simultaneously ...; in the same way as all military actions have an operational dimension, they also have a psychological dimension and a pacification dimension. ${ }^{54}$ This was translated in the very population-centric notion of 'war among the people'. ${ }^{55}$ These were recurrent themes in French texts on counterinsurgency, particularly in the Revue Militaire d'Information (RMI), a professional military journal charged with promoting counterinsurgency. Some of these articles were then included in the syllabus of the main French counterinsurgency training centre in Algeria. This was natural given the fact that both RMI and the Arzew centre were initially under the head of the new Fifth Section of the French General Staff, Colonel Lacheroy, a determined advocate of the population-centric dimension of counterinsurgency warfare. ${ }^{56}$

French promoters of counterinsurgency doctrine had no doubt that 'revolutionary warfare' - their preferred label for counterinsurgency as a highly politicised type of conflict - was 'the real total war', requiring comprehensive 'physical and moral mobilisation of the population' and 'a strictly coordinated and energetic action' by all state agents. For counterinsurgency to be total it had to include 'energetic propaganda' to recover the loyalty of the local population. ${ }^{57}$ The inevitable question then becomes how can the French Army use of brutal methods in counterinsurgency be reconciled with this population-centric counterinsurgency doctrine of total warfare?

\section{Coercion in Population-Centric Doctrine}

That French counterinsurgents often resorted to brutal methods is unquestionable. General Aussaresses, who was in charge of special operations during the Battle of Algiers (1957), was only the latest and possibly the most extreme example of a relatively long series of very outspoken testimonies by French officers. Aussaresses took pride in describing his role in the summary executions of captured Algerian insurgent leaders, because he believed this was necessary

\footnotetext{
${ }^{54}$ SHD 1H 2524, XRM - CIPCG (Arzew), L’Activité Operationnelle en Algérie, 2.

${ }^{55}$ E.g., Col. Nemo, 'La Guerre dans le Milieu Sociale', Revue de Défense Nationale, 12 (1956), 622.

${ }^{56}$ For an obviously partial but rich account see Charles Lacheroy, De Saint-Cyr à la Guerre Psychologique: Mémoires d'un Siècle (Panazol: Lavauzelle 2003).

${ }^{57}$ A. Sourys, 'Les conditions de la parade et de la riposte à la guerre révolutionnaire', Revue Militaire d'Information, 281 (1957), 92.
} 


\section{Bruno C. Reis}

to win an unconventional war. ${ }^{58}$ But Colonel Trinquier, one of the most influential officers in the development and implementation of counterinsurgency guidelines in Algeria, had written decades before: 'I am neither in favour nor against torture ..., in the same way as I am neither in favour nor against conventional weapons. ${ }^{59}$ General Salan, the French Commander-in-Chief in Algeria (1956-58), had also recorded in his memoirs a tense exchange of views with General de la Bollardière: the latter resigning because he did not want to fight a 'dirty war'; Salan merely replying that 'it is one imposed on us by the enemy'.

The total warfare mindset does seem to have contributed to the acceptance of a significant level of coercion as a military necessity in French counterinsurgency, leading to statements like the following by General Ély, the last French supremo in Indochina and Chief-of-theGeneral-Staff during most of the Algerian War: 'we do not accept any limits other than the ones the enemy accepts for himself'. ${ }^{61}$ But to reduce the French conception of counterinsurgency as a total war to a blind focus on enemy-centric kinetic action and an absence of concern for winning over the local population is facile but wrong. The very same General Ély told a President de Gaulle who was eager to see the return of French troops to strictly military roles that the new population-centric tasks performed by officers were vital: 'how could we replace all these men by civilians? It is impossible!' ${ }^{62}$ For French military chiefs, accepting no limits on counterinsurgents other than those of the insurgents also meant expanding the role of the military into population-centric tasks.

However, for the core argument of this article, the key point is not whether French counterinsurgency was violent in absolute terms, but rather how it compared with British small wars of decolonisation in terms of doctrinal principles and military practices. A number of recent books by French scholars on France's decolonisation campaigns carefully document some of the more violent aspects of French counterinsurgency and would therefore seem to vindicate the prevailing narrative of post-1945 counterinsurgency with France - alongside the

\footnotetext{
${ }^{58}$ Paul Aussaresses, Battle of the Casbah: Counter-Terrorism and Torture (New York: Enigma 2005).

${ }^{59}$ Roger Trinquier, La Guerre, (Paris: Albin Michel 1980), 173.

${ }^{60}$ Salan, Mémoires, Vol. 3, 76.

${ }^{61}$ General Paul Ély, 'Preface', Reglement de l'Action Psychologique, in M. Faivre (ed.), Le Général Paul Ély et la Politique de Défense (1956-1961) (Paris: Economica 1998 [Orig. Ed. 1958]), 14.

${ }^{62}$ Cited in Maurice Faivre (ed.), Le Général Paul Ély et la Politique de Défense (19561961) (Paris: Economica 1998), 77, reproduces Ély’s diary of 5 Mar. 1960.
} 
US - playing villain to Britain's hero. ${ }^{63}$ However, these French studies do not aim at a comparative approach that would give traction to arguments about a sharp contrast between French and British counterinsurgency; and focus systematically on abuses by the France's military, something only now starting to be done for the British case.

The main French training centre in Algeria, it should be made clear, did include some notions of military justice, namely with regard to proper arrest, even though this seems to have been an addition to the initial version. ${ }^{64}$ However, one central point in French doctrinal texts was that peacetime legislation should not be allowed to provide cover for subversion. Colonel Lacheroy, in a core text on the syllabus of the Arzew training centre, made this clear by contrasting the 'debonair justice system in a venal democracy' with the ideal for revolutionary warfare of a 'popular-political-military dictatorship, relatively pure, always hard, and if necessary brutal'. ${ }^{6}$

In view of this, it should come as no surprise that in French doctrine the military necessity of finding and fighting insurgents prevailed over the requirements of a liberal democracy. But what this meant was that the French Army was granted special legal powers that allowed it to keep in detention suspected insurgents for up to a month without charges, and a 'don't ask, don't tell' policy that opened the door to all kinds of abuses.

This is not very different, however, from British counterinsurgency use of emergency regulations as illustrated in the Malayan campaign manual and pointedly exemplified by Sir Robert Thompson: 'strict curfews, a mandatory death penalty for carrying arms, life imprisonment for providing supplies or other support to the terrorists'. ${ }^{66}$ Moreover, recent studies document an initial period when the top British official in Malaya went so far as to advocate the need to break the law in order to defeat the insurgents. ${ }^{67}$ Decades later, General

\footnotetext{
${ }^{63}$ Particularly in-depth - and with references to Indochina - is Raphäele Branche, La Torture et l'Armée pendant la Guerre d'Algérie (1954-1962) (Paris: Gallimard 2001), 424-35; see also, on how the legal system dealt with the war, Sylvie Thénault, Une Drôle de Justice: Les Magistrats dans la Guerre d'Algérie (Paris: La Découverte 2004). For a rare example of some resistance to this trend, see Henri le Mire, Histoire Militaire de la Guerre d'Algérie (Paris: Albin Michel 1982), 105-16 passim.

${ }^{64}$ SHD 1H 1115, XRM-CIPCG, Dossier d'Instruction, 130-31. All sections in this instruction manual are numbered in sequence, except this one: 51 bis.

${ }^{65}$ SHD 1H 2524, XRM - CIPCG (Arzew), Charles Lacheroy, La Guerre Révolutionnaire: Leçons de l'action Viet-minh et communiste en Indochine.

${ }^{66}$ Thompson, Defeating Communist Insurgency, 52-3.

${ }^{67}$ E.g., Huw Bennett, “'A very salutary effect”: The Counter-Terror Strategy in the Early Malayan Emergency, June 1948 to December 1949', Journal of Strategic Studies, 32/3 (2009), 433.
} 
Kitson was still highlighting the need for British counterinsurgency to close the legal 'loophole concerning disorder which is not aimed at overthrowing the government' and armed insurgency. ${ }^{68}$

And the last major British decolonisation campaign in Aden in the mid-1960s offers some parallels, if not in scale, certainly in dynamics, rationale and political attitudes with the French campaign in Algiers. Namely, a specialised interrogation unit in the main detention centre for suspected insurgents in Aden became the focus of accusations of torture. ${ }^{69}$ Despite the damning conclusions of the so-called Bowden Report, the official argument from the Army remained that even if there had been a 'large number of allegation and many were of a serious nature' and they were 'not dealt expeditiously' there was good reason for this. The only use of 'minimum necessary force' I could find in documents pertaining to this campaign was in justifying 'raids' that were deemed excessively brutal by the report. The top British official in Aden sums it up by reacting to the report by emphasising that: 'the only instrument by which the Government could make itself aware of terrorists' intentions was the interrogation Centre. It was therefore of overriding important that nothing should be done that might hamper the operations of the Centre' namely insurgent 'propaganda' targeting it. $^{70}$

Furthermore, some authors, including Rod Thornton who advocates the centrality of minimum force in British counterinsurgency, have argued that brutal interrogation methods, though kept out of formal guidelines, were nonetheless common practice throughout British small wars, being transmitted informally between interrogators. If this is confirmed by further research, it can be seen as an additional sign of the underdevelopment of doctrine in fields outside of conventional warfare; and evidence of a greater reluctance to set down guidelines concerning this particularly sensitive area, even in classified manuals; as well as, again, a very coercive side to British counterinsurgency. ${ }^{71}$

\footnotetext{
${ }^{68}$ Kitson, Low Intensity Operations, 3.

${ }^{69}$ Julien Paget, Last Post: Aden 1964-1967 (London: Faber and Faber 1969), 128-9.

${ }^{70}$ Roderick Bowen, Report on Procedures for the Arrest, Interrogation and Detention of Suspected Terrorists in Aden (London: HMSO 1966); see also TNA: citations from DEFE 24/253 UK-Army, Comments of the Section of the Bowen Report Entitled 'Allegations of Cruelty and Torture': Idem, H.C. Turnbull, Note on the Security Situation in Aden in December (25 Jan. 1966);

${ }^{71}$ Rod Thornton, 'Getting it Wrong: The Crucial Mistakes in Early Stages of the British Deployment in the Northern Ireland Campaign (August 1969 to March 1972)', Journal of Strategic Studies, 30/1 (2007), 94 and footnote 104; see also Peter Taylor, Brits: The War against the IRA (London: Bloomsbury 2001), 65.
} 
As for Portugal, one influential officer in the development of Portuguese counterinsurgency doctrine, Colonel Hermes Oliveira, went so far as to criticise as a fatal weakness Western legal concerns regarding the treatment of insurgents. ${ }^{72}$ Official Portuguese military doctrine highlighted 'a growing difficulty in suffocating brutally any kind of protest of the people against their own government, because of the repercussions that this has on global public opinion as well as internally'. ${ }^{73}$ Clearly, even authoritarian Western states such as Portugal could be concerned with an excessive use of force, if only for the negative impact on national and international public opinion; but not to the point of endangering the perceived priority of getting vital intelligence. Portuguese counterinsurgency guidelines stated that although it was important for troops engaged in counterinsurgency to know and observe the law, 'ordinary law could be modified' by special legislation adapted to a 'state of siege'. ${ }^{74}$ Furthermore, Portuguese doctrine, as in the other two cases, established relatively lax rules for the treatment of alleged insurgents. Even if a generic principle of 'humane treatment' was affirmed, it was stressed that, unlike regular troops protected by the Geneva Convention, 'it is very hard in subversive warfare to establish the exact status of captured combatants'. ${ }^{75}$ The order of priorities governing the treatment of prisoners according to Portuguese doctrine should be to: 'make sure they do not escape or are released'; 'obtain the maximum of information'; 'turn them for future use'; 'avoid resentment from innocent prisoners'.

It is clear therefore that a concern with the population-centric dimension of counterinsurgency was present in doctrinal guidelines in the three cases being analysed, but that very coercive measures were still allowed if they were seen as strategically necessary. Liberal democratic states could hardly advocate torture openly; in fact, it seems unlikely that any kind of state would do that, even if only out of concern with its external image. But, of course, doctrinal military guidelines were not public. Discretion would still probably seem wise, and a lot could be left unsaid if formal guidelines - as was the case of counterinsurgency doctrines in all three cases - pointed in certain directions, namely: how vital it was to get timely intelligence; the possibility of changing the law to enable harsher measures of

\footnotetext{
${ }^{72}$ Hermes de A. Oliveira, Guerra Revolucionária (Lisboa: [s.n.] 1962), 229-30.

${ }^{73}$ Portugal-EME, O Exército na Guerra Subversiva [The Army in Subversive Warfare], Vol. 1, xi.

${ }^{74}$ Ibid., Vol. 4, I/3. Significantly this is the very same page where the principle of minimum force is mentioned.

${ }^{75}$ Ibid., Vol. 5, I/8-9.

${ }^{76}$ Ibid., Vol. 5, I/8-9.
} 
population control and punishment; the lack of clarity regarding the status and treatment of captured insurgents.

One important question remains: why have instances of French brutality in counterinsurgency campaigns, at least until recently, been more widely known and discussed than their equivalents in British or Portuguese campaigns? This may simply be because abuses were more widespread and institutionalised in French counterinsurgency. ${ }^{77}$ Another factor also worth considering is the significantly greater intensity of French counterinsurgency campaigns - adding urgency to getting intelligence on the insurgents - in Indochina and Algeria when compared with all other instances of small wars of decolonisation, and particularly with the very low-intensity British campaign in Kenya. ${ }^{78}$ Still, even if French counterinsurgency was more coercive for whatever reasons, why would French officers not be brutal but silent? A possibility worth considering is the greatly polarised nature of French political culture, with, on the one hand, a cult of the state and of salut public as the embodiment of national security; and, on the other, a tradition of public intellectuals openly challenging state security concerns going back at least to Zola and the Dreyfus Affair. ${ }^{79}$ This may help to explain both the relative abundance of candid testimonies about brutal practices by French officers, who claimed that they were doing what was necessary for state security reasons, alongside loud public criticism of them as unacceptable violations of basic human

\footnotetext{
${ }^{77}$ Probably the first to make the case in these terms is Peter Paret, French Revolutionary Warfare from Indochina to Algeria: The Analysis of a Political and Military Doctrine (London: Pall Mall P 1964), 104-5. But he is also careful to note that this does not mean that a strong coercive dimension was exclusive to French counterinsurgency campaigns.

${ }^{78}$ Cf. John Cann, Counterinsurgency in Africa: The Portuguese Way of War, 19611974 (Westport: Greenwood P 1997), 189, on data on deaths per day of war per thousand combatants - 0.0017 British Malaya, 0.0075 Portuguese Africa, 0.0107 French Algeria, 0.0365 US war in Vietnam, 0.0691 French Indochina. Kenya was so insignificant in this respect that it is not even listed by Cann and others; data is not contested as to the number of British (63) and local allied combatants killed (1200), but estimates range from 11,000 to 20,000 insurgents/suspects killed or even 100,000s, cf. Daniel Branch, 'The enemy within: loyalists and the way against Mau Mau in Kenya', Journal of African History, 48/2 (2007), 292 footnote 6.

${ }^{79}$ It is revealing that similar arguments regarding the prevalence of state security are held by men with deeply opposed views on counterinsurgency in Algeria; Antoine Argoud, La Décadence, l'Imposture et la Tragédie (Paris: Fayard 1974), 157; and General de Gaulle, cited in Alain Peyrefitte, C'Était de Gaulle (Paris: Fayard 1995), 126; for the denouncing of this Realpolitik by one of the most vocal intellectual critic of the Algerian War see Pierre Vidal-Naquet, La Raison d'État (Paris: La Découverte 2002 [Orig. Ed. 1962]).
} 
rights. Mainstream British media and censored Portuguese media were respectively less willing and unable to denounce excessive violence in British and Portuguese counterinsurgencies. ${ }^{80}$

Bernard Fall refers to a French 'Cartesian rationale for the use of torture in revolutionary warfare'. ${ }^{81}$ This certainly produced murderous results, namely in Algeria. But by using this expression Fall was pointing to a larger issue that exists in counterinsurgency as an intelligence-driven conflict in which fighting the enemy implies finding him: sometimes there seems to be a strategic logic in using very violent means to get vital information. In other words, the challenge of finding insurgents without falling into abuses is not exclusive to past French counterinsurgency.

Interestingly, both the concepts of minimum force and total warfare were incorporated into the multivolume Portuguese manual on counterinsurgency and internal security. This shows that a necessary contradiction between them was not evident in the 1960s, if, as was the case, minimum force was understood to be restricted to riot control, not counterinsurgency proper and total warfare was equated with a comprehensive approach to counterinsurgency. ${ }^{82}$

\section{Doctrinal Definitions of Counterinsurgency}

But how are we to define synthetically British counterinsurgency during the wars of decolonisation if not in terms of minimum force and winning hearts and minds? The best answer is to turn to the dominant conceptualisation of counterinsurgency in British, as well as French and Portuguese, doctrines during these decolonisation campaigns.

The main concern of British counterinsurgency was to develop a civil-military, offence-defence, inkspot, state-building comprehensive approach to counter insurgency at every level. The paradigmatic example of this is the Briggs/Templer Plan for Malaya, an inkspot strategy of pacification through clear-hold-build efforts systematically targeting different regions. ${ }^{83}$ Sir Robert Thompson summarises it very

\footnotetext{
${ }^{80}$ On the normally close relationship between Whitehall and Fleet Street see Susan L. Carruthers, Winning Hearts and Minds: British Governments, the Media and Colonial Counterinsurgency, 1944-1960 (London: Leicester UP 1995), 266-7.

${ }^{81}$ Bernard Fall, 'Introduction', in Roger Trinquier, Modern Warfare: A French View of Counterinsurgency (London: Pall Mall P 1964 [Orig. Fr. Ed. 1961]), xv.

${ }^{82}$ Portugal-EME, O Exército na Guerra Subversiva [The Army in Subversive Warfare], Vol. 4, II/22.

${ }^{83}$ TNA CAB 21/1681 Federation [of Malaya], Plan for the Elimination of the Communist Organization and Armed Forces in Malaya [Briggs Plan]. See also The Briggs Plan, UK-HQ-Malaya Command, III/2-5.
} 
aptly: to regain control of the country in 'oil-spot' offensives, i.e., 'secure your base areas first' so as to control the most 'highly developed areas of the country', and accept if need be penetration from 'inaccessible borders' ${ }^{84}$ The corollary of this, however, was not minimum force, but that 'clear operations will ... be a waste of time unless' they are followed 'immediately' by 'hold operations', including the establishment of strategic hamlets, local militias and strict control of locals and vital commodities. Counterinsurgency was therefore conceptualised as a 'fight' for the 'control of the population' in 'clear-and-hold operations'. ${ }^{85}$

This has close parallels in French and Portuguese counterinsurgency doctrine. In fact, the principle of tache d'huile/oil-spot for colonial pacification was famously advocated back in the nineteenth century by the French General Gallieni, and was exemplarily applied in the Algerian War by General Challe. ${ }^{86}$ To quote Trinquier, French counterinsurgency was conceived as a fight 'against an armed clandestine organisation whose essential role is to impose its will upon the population', requiring not spectacular 'operational warfare' but a slow effort 'methodically pursued'. He concluded that the insurgency 'will not end until we have organised the population and created an efficient intelligence service'. ${ }^{87}$

The Portuguese manual also made very clear that counterinsurgency consisted of a systematic comprehensive struggle against the insurgents and for the population; therefore, 'the solution for this type of conflict can never be obtained by armed force alone' ${ }^{88}$

In terms of doctrinal development, the differences in regime-type between the three cases seem, consequently, largely irrelevant. Portugal had an authoritarian regime, but was part of the Western bloc and had an interest in avoiding criticism from key allies. The Portuguese government was therefore determined to show its ability to win over

\footnotetext{
${ }^{84}$ Thompson, Defeating Communist Insurgency, 57.

${ }^{85}$ Ibid., 111-12, 116.

${ }^{86}$ See, e.g., Douglas Porch, 'Bugeaud, Gallieni, Lyautey: The Development of French Colonial Warfare', in P. Paret (ed.), Makers of UK-Modern Strategy: From Machiavelli to the Nuclear Age (Oxford: OUP 1986), 389 passim; François-Marie Gougeon, 'The Challe Plan: Vain Yet Indispensable Victory', Small Wars and Insurgencies, 16/3 (2005), 293-316. Challe explains his approach and cites in extenso from key documents in Maurice Challe, Notre Révolte (Paris: Presses de la Cité 1968), 91-105; see also SHD, 1H 1930, Note C-e-C X Region Militaire, 10 Dec. 1959, appendix La Méthode de pacification generale; Claude Delmas, 'Interview avec le Générale Challe', Revue Défense Nationale, 17 (1961), 577-94.

${ }^{87}$ Roger Trinquier, Modern Warfare: A French View of Counterinsurgency (London: Pall Mall P 1964 [Orig. Fr. Ed. 1961]), 8-9, 48-9.

${ }^{88}$ Portugal-EME, O Exército na Guerra Subversiva [The Army in Subversive Warfare], Vol. 1, xi.
} 
the local populations in its overseas territories. Britain and France were democratic but also imperial powers, and an empire by definition is not a liberal democratic regime - not even when the territories were formally not colonies like Algeria - especially in times of crisis. Differences in military capabilities also did not matter much, because Portugal mobilised all available resources and drafted all available manpower - making it the third most militarised country in the world; and the insurgents it faced were still as a rule less numerous, less wellarmed, less well-trained and less organised, and, in certain areas, including air and naval power, at a disadvantage until the very end of these small wars. ${ }^{89}$

The need to systematically eliminate insurgents and regain control of the local population was therefore key in these three cases. The big difference lay in the fact that the British preferred to wage comprehensive counterinsurgency through civil-military committees, keeping many state-building tasks in the hands of civilian officials; French and Portuguese counterinsurgency state-building was more militarised, with officers taking over many governance tasks. Nevertheless, it is worth highlighting that the British comprehensive approach to counterinsurgency was conducted in its most paradigmatic and successful campaigns under the ultimate control of military officers General Templer was formally supremo in Malaya; more informally, General Erskine was in control of all key aspects of the campaign in Kenya. Moreover, British military thinking and doctrine insisted that to be successful the counterinsurgent has to keep the initiative and be militarily effective. ${ }^{90}$ So strong was this concern that some guidelines in British counterinsurgency doctrine could easily be presented - in isolation - as an example of a coercive approach to counterinsurgency, when in fact they represent the more coercive aspect of a comprehensive approach to small wars. Templer's Foreword to ATOM, for instance, stated: 'The job of the British Army here [in Malaya] is to kill or capture Communists'. He went on to highlight key points related to this aim including 'the need for offensive action'. ${ }^{91}$ The 1970 British counterinsurgency manual established that both 'a clear cut political policy and offensive action by the security forces are essential for

\footnotetext{
${ }^{89}$ In 1974, with 31 military per thousand Portugal was only surpassed by Israel and Vietnam, cf. Kenneth Maxwell, The Making of Portuguese Democracy (Cambridge: Cambridge UP 1995), 35.

${ }^{90}$ Kitson, Low Intensity Operations, $134-5$ passim; Thompson, Defeating Communist Insurgency, 58.

${ }^{91}$ Templer, 'Foreword', xi. See also Erskine, 'Foreword'.
} 
seizing and holding the initiative' so that 'security forces must be imbued with an aggressive spirit'. ${ }^{92}$

\section{An Alternative to Minimum Force}

No reference whatsoever to minimum force was made in the three British counterinsurgency manuals issued during the period of the wars of decolonisation between 1945 and 1970. The traditional portrait of British counterinsurgency overseas as being completely dominated, since at least the early twentieth century, by a central norm of minimum force is therefore largely, if not entirely, a myth, not only in terms of military practice but also, and even more clearly, of doctrinal principles.

The authors wishing to continue to advocate the centrality of minimum force in British counterinsurgency doctrine overseas during the late colonial period from 1945 to 1970 need to offer a satisfying answer to at least two key questions: Why would the British military go to the trouble of developing doctrine - namely three manuals - to deal specifically with counterinsurgency, and neglect to include in them an allegedly key principle of minimum force? Where is the evidence for a generalised practice of minimum force in British counterinsurgencies overseas before 1970?

What then is the alternative provided by this article? Choosing between destruction and construction, between winning locals and coercing insurgents was never an option in British counterinsurgency doctrine, nor, for that matter, in Portuguese and French counterinsurgency doctrines. In the three cases analysed, it was the fact that both destruction and construction, killing insurgents and controlling locals, were seen as important that led to the emergence of a comprehensive approach to counterinsurgency so typical of that period and so topical nowadays.

The revision of the prevailing analysis of British, French and Portuguese counterinsurgency doctrine advocated in this article has at least three major implications:

First, in terms of the historical record, it shows it is inaccurate to present counterinsurgency during the campaigns of decolonisation in terms of a sharp dichotomy between a successful British populationcentric doctrine of minimum force for winning hearts and minds, and a failed French or Portuguese enemy-centric doctrine of terror and coercion. In fact, when British, French and Portuguese doctrines specifically designed for counterinsurgency finally emerged they shared important characteristics. These three doctrines mandated both

\footnotetext{
${ }^{92}$ UK-MoD, Land Operations: Vol. III, 5, 17-21.
} 
coercion of insurgents and securing of locals. If we want to continue to use these labels, then these British, French and Portuguese counterinsurgency doctrines must be seen as enemy-centric in certain aspects and population-centric in others; without the latter necessarily entailing a softer, certainly not by today's standards, approach to counterinsurgency - as shown by the ample usage of forced resettlement as a key tool for regaining control of the population in Malaya, Algeria or Angola.

Second, regarding the relationship between formal guidelines and informal practice, this article emphasises that by definition doctrine is not developed in an intellectual void, it aims to reflect key aspects of combat experience. The latter will be especially true of successful theatre-specific doctrine developed during ongoing conflicts. Moreover, doctrine can - and is meant to - have an important authoritative impact on new waves of troops so that they avoid some of the worse mistakes and benefit from some of the best practices of their predecessors. It seems only logical to think that it is not an accident that successful commanders in these campaigns, like General Templer, believed improvements in counterinsurgency practice required the development and implementation of doctrine adapted to these unconventional conflicts.

Third, in terms of lessons for today, there are a number of conclusions that can be drawn, namely regarding the principle of minimum force. Even when correctly understood as minimum necessary force, an often missing but very important qualifier - it, or any other similar population-centric norm, does not solve the great difficulty of determining the amount of force necessary to successfully defeat an insurgency, particularly because, and this is the heart of the matter, the enemy also gets a vote regarding the level of intensity of the conflict, which can vary significantly in small wars, despite the once popular misnomer of low intensity operations. Decolonisation campaigns, in particular the French one in Indochina, provide cautionary lessons regarding the difficulties of fighting well-armed, well-organised massive insurgencies such as the one carried out by the Viet-Minh which we might call an 'hybrid war' avant la lettre. ${ }^{93}$

Minimum force provides even less of a solution for the extremely complex problems of state-building, governance and legitimacy across very different political contexts. This was already a major problem for late colonial interventions in the era of decolonisation, it is even more so today for overseas interventions in a postcolonial era.

\footnotetext{
${ }^{93}$ General André Beaufre, La Guerre Révolutionnaire: Les Nouvelles Formes de la Guerre (Paris: Fayard 1972), 227-9.
} 


\section{Bruno C. Reis}

The fact that British counterinsurgency doctrine during this vital period of its development was actually a much more flexible combination of coercion, attraction and control than we are led to believe by the notion of minimum force winning hearts and minds as presented in mainstream analysis points to a major risk. The risk that a mistaken belief in a uniquely successful principle of minimum force as a key component of victory in population-centric British counterinsurgency in campaigns like Malaya may create dangerously optimistic expectations for counterinsurgency today in relation to aspects such as:

- the availability of timely intelligence on legitimate targets;

- the level of civilian and military casualties;

- the ability of counterinsurgents to unilaterally control the levels of violence;

- the likelihood and cost of success in complex wars among the people.

Alongside these cautionary notes, there is, however, a notable convergence between these three cases on some of the changes needed to adapt a conventional army to counterinsurgency. Therefore doctrine developed during this period is very much worth pondering when analysing and dealing with counterinsurgencies today, but with due caution and rigour so as to look carefully at mistakes and costs of past campaigns as well as successes.

Lastly, the most difficult question: What is essential to defeat an insurgency according to these three cases? The best answer is that it is indispensable to have a doctrine that is specifically designed for counterinsurgency and well adapted to local circumstances. But although good doctrine intelligently applied is necessary for making conventional Armed Forces more capable in unconventional warfare, it is not sufficient to ensure victory. Additionally there must be a politically realistic ultimate aim taking into account the necessarily protracted and highly politicised nature of this type of conflict. The main factor determining the different end-result of these campaigns was the fact that Britain had a more realistic definition of victory, in the context of the post-1945 international system, in terms of controlled decolonisation, than France or Portugal. This allowed Britain to sometimes successfully present the violence of the insurgents as the main obstacle to self-rule, and frame successful counterinsurgency as the best way to secure independence. The key to victory is the ability to exploit positive doctrinal and military results in the pursuit of a realistic strategic aim.

In conclusion, it should be made clear that this article does not contend that British counterinsurgency doctrine entirely lacked 
discrimination in the use of force in its small wars of decolonisation or that doctrine was irrelevant in British success in some of these campaigns. However, it does highlight the fact that British counterinsurgency was conducted in a more complex, and also often in a more coercive way than long-prevailing analyses based on the alleged centrality of a principle of minimum force would suggest. British counterinsurgency doctrine, in its comprehensive approach, was also less unique than is usually claimed, being closer to other examples of late colonial counterinsurgency doctrines.

This article therefore challenges the usual explanation of British success, and French and Portuguese failure in small wars. Ironically, it can even be argued that French and Portuguese counterinsurgencies suffered strategic defeat because of an excessive, rather than an insufficient, belief in the power of population-centric counterinsurgency. French and Portuguese leaders seemed to believe, until it was too late, that new counterinsurgency doctrine based on soft psychological warfare could replace hard political choices, and that officers trained according to new counterinsurgency doctrines could win the hearts and minds of local overseas populations converting them into loyal citizens of a multiracial fatherland. British aims regarding local populations were usually more modest and achievable: controlling locals by isolating them from insurgents and providing them with security, and then getting them to accept a gradual process of decolonisation; this was done, however, without resorting to the doctrinal principle of minimum force, and was just part of the story of British counterinsurgency, which also required a significant measure of coercion both in principle and in practice.

\section{Acknowledgements}

Different versions of this article were presented at a joint King's College/Science Po seminar at Cumberland Lodge (October 2006); at the BISA Conference in Cambridge (December 2007); at the 49th ISA Convention in San Francisco (March 2008); and as part of my PhD. Thanks are due to all those who commented, sometimes very critically, on previous versions of this article, and in particular to Andrew Mumford, Caroline Kennedy-Pipe, Christian Olsson, Didier Bigo, Huw Bennett, John Mackinley, Srinath Raghavan, Theo Farrell, Warren Chin and in particular to my supervisor - Sir Lawrence Freedman. Thanks are also due to two anonymous referees and the editors of the $J S S$, and friends and faculty at King's College London, as well as at the IEEI and FEUNL for their insights and their support during an especially difficult period of my life. An FCT fellowship of the Portuguese Ministry of Science and EU funding supported research for 
this article. Last but not least, many thanks to the marvellous staff of the Santa Marta Hospital and to my family, especially Noélia, Sofia and my parents. All deficiencies in this text are despite their best efforts and entirely my responsibility.

\section{Bibliography}

Anderson, David, Histories of the Hanged: Britain's Dirty War in Kenya and the End of Empire (London: Weidenfeld and Nicolson 2005).

Argoud, Antoine. La Décadence, l'Imposture et la Tragédie (Paris: Fayard 1974).

Ascherson, Neal, 'The Breaking of the Mau Mau', New York Review of Books, 52/6 (2005), $<$ www.nybooks.com/articles/17896>.

Ash, Jenny, Empire Warriors (London: BBC 2004) [2 DVDs - 2006].

Aussaresses, Paul, Battle of the Casbah: Counter-Terrorism and Torture (New York: Enigma 2005).

Beaufre, André, La Guerre Révolutionnaire: Les Nouvelles Formes de la Guerre (Paris: Fayard 1972).

Beckett, Ian, 'Low-Intensity Conflict: Its Place in the Study of War', in D.A. Charters et al. (eds), Military History and the Military Profession (Westport: Praeger 1992), 121-9.

Bennett, Huw, 'British Minimum Force', Small Wars and Insurgencies, 21/3 (2010), 459-75.

Bennett, Huw, 'The Other Side of COIN: Minimum and Exemplary Force in British Army Counterinsurgency in Kenya', Small Wars and Insurgencies, 18/4 (2007), 638-64.

Bennett, Huw, "AA Very Salutary Effect”: The Counter-Terror Strategy in the Early Malayan Emergency, June 1948 to December 1949', Journal of Strategic Studies, 32/3 (2009), 414-44.

Betz, David, 'Insurgency and Counterinsurgency', in Robert Denemark et al. (eds), The International Studies Encyclopedia, Blackwell Reference Online, < http://www.isacompendium. com/subscriber/tocnode?id=g9781444336597_chunk_g978144433659711_ss1-10>.

Bickel, Keith, Mars Learning: The Marine Corps Development of Small Wars Doctrine, 19151940 (Boulder: Westview 2001).

Bowen, Roderick, Report on Procedures for the Arrest, Interrogation and Detention of Suspected Terrorists in Aden (London: HMSO 1966).

Branch, Daniel, 'The enemy within: loyalists and the war against Mau Mau in Kenya', Journal of African History, 48/2 (2007), 291-315.

Branche, Raphäele, La Torture et l'Armée pendant la Guerre d'Algérie (1954-1962) (Paris: Gallimard 2001).

Brown, Michael (ed.), Grave New World: Security Challenges in the Twenty-First Century (Washington DC: Georgetown UP 2003).

Cable, Larry, 'Reinventing the Round-Wheel: Insurgency, Counterinsurgency, and Peacekeeping Post Cold War', Small Wars and Insurgencies, 4/2 (1993), 228-62.

Cann, John, Counterinsurgency in Africa: The Portuguese Way of War, 1961-1974 (Westport: Greenwood P 1997).

Carruthers, Susan, L., Winning Hearts and Minds: British Governments, the Media and Colonial Counterinsurgency, 1944-1960 (London: Leicester UP 1995).

Challe, Maurice, Notre Révolte (Paris: Presses de la Cité 1968).

Charters, David, 'The British Adaptation to Low Intensity Operation from Palestine to Northern Ireland', in David Charters (ed.), Armies in Low-Intensity Conflict (London: Brassey's 1989).

Delmas, Claude, 'Interview avec le Générale Challe', Revue Défense Nationale, 17 (1961), 57794. 
Dixon, Paul, “'Hearts and Minds?” British Counter-Insurgency from Malaya to Iraq', Journal of Strategic Studies, 32/3 (2009), 347-513.

Elkins, Caroline, Imperial Reckoning: The Untold Story of Britain's Gulag in Kenya (New York: Henry Holt 2005).

Elstein, David, 'The End of The Mau Mau', New York Review of Books, 52/11 (2005), $<$ www.nybooks.com/articles/18096>.

Ély, General Paul, 'Preface', Reglement de l'Action Psychologique, in M. Faivre (ed.), Le Général Paul Ély et la Politique de Défense (1956-1961) (Paris: Economica 1998 [Orig. Ed. 1958]).

Erskine, George, 'Foreword', in A Handbook of Anti-Mau Mau Operations (Nairobi: EA-GHQ 1954).

Faivre, Maurice (ed.), Le Général Paul Ély et la Politique de Défense (1956-1961) (Paris: Economica 1998).

Fall, Bernard, 'Introduction' in Roger Trinquier, Modern Warfare: A French View of Counterinsurgency (London: Pall Mall P 1964 [Orig. Fr. Ed. 1961]).

France - Ministère de l'Algérie-Service Affaires Algériennes, Guide de l'officier des affaires algériennes (Paris: SAA 1959).

Gougeon, François-Marie, 'The Challe Plan: Vain Yet Indispensable Victory' Small Wars and Insurgencies, 16/3 (2005), 293-316.

Hoffman, Frank, 'Neo-Classical Counterinsurgency', Parameters 37/2 (2007), 71-87.

Holland, Robert, Britain and the Revolt in Cyprus 1954-1959 (Oxford: Clarendon P 1998).

Howard, Michael, 'The Military Factor in European Expansion', in H. Bull (ed.), The Expansion of European Society (Oxford: Clarendon P 1984), 33-42.

Hyam, Ronald, Britain's Declining Empire: The Road to Decolonization (Cambridge: Cambridge UP 2006).

Joes, Anthony, Resisting Rebellion: The History and Politics of Counterinsurgency (Lexington: U of Kentucky P 2006).

Jones, Alun, 'Training and Doctrine in the British Army since 1945', in M. Howard (ed.), The Theory and Practice of War (Bloomington: Indiana UP 1965), 311-33.

Kitson, Frank, Low Intensity Operations: Subversion, Insurgency, Peacekeeping (London: Faber and Faber 1971).

Lacheroy, Charles, De Saint-Cyr à la Guerre Psychologique: Mémoires d'un Siècle (Panazol: Lavauzelle 2003).

Lacheroy, Charles, La Guerre Révolutionnaire: Leçons de l'action Viet-minh et communiste en Indochine.

Le Mire, Henri, Histoire Militaire de la Guerre d’Algérie (Paris: Albin Michel 1982).

Mahnken, Thomas G., 'The British Approach to Counter-Insurgency: An American View', Defense and Security Analysis, 23/2 (2007), 227-32.

Maxwell, Kenneth, The Making of Portuguese Democracy (Cambridge: Cambridge UP 1995).

Mazower, Mark, 'Violence and the State in the Twentieth Century', The American Historical Review, 107/4 (2002), 1158-78.

McInnes, Colin, Hot War, Cold War: The British Army's Way in Warfare 1945-95 (London: Brassey's 1996).

Mockaitis, Thomas, British Counterinsurgency 1919-1960 (London: Macmillan 1990).

Mockaitis, Thomas, 'Minimum Force, British Counter-Insurgency and the Mau Mau Rebellion: A Reply', Small Wars and Insurgencies, 3/2 (1992), 87-9.

Mockaitis, Thomas, 'A New Era of COIN', RUSI Journal, 136/1 (1991), 73-8.

Mockaitis, Thomas, 'The Origins of British Counter-Insurgency', Small Wars and Insurgencies, 1/ 3 (1990), 209-25.

Nagl, John, Counterinsurgency Lessons from Malaya and Vietnam: Learning to Eat Soup with a Knife (Westport: Praeger 2002).

Nemo, Colonel, 'La Guerre dans le Milieu Sociale', Revue de Défense Nationale, 12 (1956), 605-23.

Newsinger, John, British Counter-Insurgency from Palestine to Northern Ireland (Basingstoke: Palgrave 2002). 


\section{Bruno C. Reis}

Newsinger, John, 'Minimum Force, British Counter-Insurgency and the Mau Mau Rebellion', Small Wars and Insurgencies, 3/1 (1992), 47-57.

Norris, Jacob, 'Repression and Rebellion: Britain's Response to the Arab Revolt in Palestine of 1936-39', Journal of Commonwealth Imperial History, 36/1 (2008), 25-45.

Oliveira, Hermes de Araújo, Guerra Revolucionária (Lisboa: [s.n.] 1962).

Paget, Julian, Counterinsurgency Campaigning (London: Faber and Faber 1967).

Paget, Julian, Last Post: Aden 1964-1967 (London: Faber and Faber 1969).

Pahlavi, Pierre, La guerre révolutionnaire de l'armée française en Algérie (1954-1961): Entre esprit de conquête et conquête des esprits (Paris: L'Harmattan 2002).

Paret, Peter, French Revolutionary Warfare from Indochina to Algeria: The Analysis of a Political and Military Doctrine (London: Pall Mall P 1964).

Peyrefitte, Alain, C’Était de Gaulle (Paris: Fayard 1995).

Porch, Douglas, 'Bugeaud, Gallieni, Lyautey: The Development of French Colonial Warfare', in P. Paret (ed.) Makers of UK-Modern Strategy: From Machiavelli to the Nuclear Age (Oxford: OUP 1986), 376-407

Portugal - EME, O Exército na Guerra Subversiva [The Army in Subversive Warfare] EGS, 5 vols (Lisboa: EME-IAEM 1963).

Salan, Raoul, Mémoires: Fin d'un Empire, 3 vols. (Paris: Presses de la Cité 1970).

Segev, Tom, One Palestine, Complete (New York: Owl Books 2001).

Shy, John and Thomas Collier, 'Revolutionary War', in P. Paret (ed.), Makers of Modern Strategy: From Machiavelli to the Nuclear Age (Oxford: Clarendon P 1986), 815-62.

SIPRI Yearbooks, <www.sipri.org/contents/publications/yearbooks.html>.

Sourys, A., 'Les conditions de la parade et de la riposte à la guerre révolutionnaire', Revue Militaire d'Information, 281 (1957), 91-111.

Taylor, Peter, Brits: The War against the IRA (London: Bloomsbury 2001).

Templer, Sir Gerald, 'Foreword', in The Conduct of Anti-Terrorist Operations in Malaya [ATOM] (Kuala-Lumpur: HQ-MC 1954).

Thénault, Sylvie, Une Drôle de Justice: Les Magistrats dans la Guerre d'Algérie (Paris: La Découverte 2004).

Thompson, Robert, Defeating Communist Insurgency: Experiences from Malaya and Vietnam (London: Chatto and Windus 1966).

Thompson, Robert, No Exit from Vietnam (New York: David MacKay 1969).

Thornton, Rod, 'The British Army and the Origins of its Minimum Force Philosophy', Small Wars and Insurgencies, 15/1 (2004), 83-106.

Thornton, Rod, 'Getting it Wrong: The Crucial Mistakes in Early Stages of the British Deployment in the Northern Ireland Campaign (August 1969 to March 1972)', Journal of Strategic Studies, 30/1 (2007), 73-107.

Thornton, Rod, “'Minimum Force”: A Reply to Huw Bennett', Small Wars and Insurgencies, 20/1 (2009), 215-26.

Townshend, Charles, Britain's Civil Wars: Counterinsurgency in the Twentieth Century (London: Faber and Faber 1986).

Townshend, Charles, 'In Aid of the Civil Power: Britain, Ireland, and Palestine 1948', in D. Marston et al. (eds), Counterinsurgency in UK-Modern Warfare (Wellingborough: Osprey 2008), 19-36.

Trinquier, Roger, La Guerre (Paris: Albin Michel 1980).

Trinquier, Roger, Modern Warfare: A French View of Counterinsurgency (London: Pall Mall P 1964 [Orig. Fr. Ed. 1961]).

UK - East Africa-GHQ, A Handbook of Anti-Man Man Operations (Nairobi: EA-HQ 1954).

UK - HQ-Malaya Command, The Conduct of Anti-Terrorist Operations in Malaya (ATOM), 2nd Rev. Ed (Kuala-Lumpur: HQ-MC 1954).

UK - Ministry of Defence, Land Operations: Vol. III: Counter-Revolutionary Operations: Part 3. Counter Insurgency, Army Code 70516 (Part 3) (London: HMSO Jan. 1970). 
Vidal-Naquet, Pierre, La Raison d'État (Paris: La Découverte 2002 [Orig. Ed. 1962]).

Villatoux, Paul and Marie Villatoux, La Republique et son armée face au peril subversif: guerre et action psychologiques en France, 1945-1960 (Paris: Les Indes Savantes 2005).

Walker, Jonathan, Aden Insurgency: The Savage War in South Arabia 1962-1967 (Staplehurst: Spellmount 2005).

War Office, Imperial Policing and Duties in Aid of the Civil Power (London: HMSO 1949). 